\title{
Microbial Properties of Lowland Rice Soil as Affected by Nutrient Management Practices and Microbial Inoculants
}

\author{
Parkash Verma, Y.V. Singh*, Anil K. Choudhary and Sunita Gaind \\ Indian Agricultural Research Institute, New Delhi 110 012, India \\ *Corresponding author
}

\begin{tabular}{|c|}
\hline Keywords \\
\hline $\begin{array}{l}\text { Lowland rice, } \\
\text { Nutrient } \\
\text { management } \\
\text { practices, Microbial } \\
\text { inoculants, MBC, } \\
\text { FDA, Alkaline } \\
\text { phosphatase } \\
\text { activity. }\end{array}$ \\
\hline Article Info \\
\hline $\begin{array}{l}\text { Accepted: } \\
27 \text { September } 2017 \\
\text { Available Online: } \\
10 \text { October } 2017\end{array}$ \\
\hline
\end{tabular}

A B S T R A C T

A field study was conducted during Kharif 2016 at the research farm of ICAR Complex for NEH Region (Umiam) Barapani, Meghalaya to find out the effect of different nutrient management practices and microbial inoculants on microbial properties in soil of lowland rice in Eastern Himalayas. The experiment was laid out in split plot design with 12 treatment combinations and 3 replications. The main plots consisted of 3 different nutrient management practices viz. 100\% organic, 100\% inorganic (recommended dose of fertilizer-RDF) and integrated nutrient management- INM (75\% RDF+ 25\% FYM) while in the sub plot there were 4 treatments viz. control, Azospirillum, Azospirillum + PSB, Azospirillum + PSB + ZnSB. Results showed that soil alkaline phosphatase activity was found to be higher at 60 days after transplanting (DAT) and it declined at harvesting stage. The highest value of alkaline phosphatase activity was recorded under organic nutrient management at $60 \mathrm{DAT}(162.58 \mu \mathrm{g} \mathrm{p}-\mathrm{NP} / \mathrm{g}$ soil/ $\mathrm{hr})$ and at harvest $(105.92 \mu \mathrm{g} \mathrm{p}-\mathrm{NP} / \mathrm{g}$ soil/ hr) and at both the stages it was significantly higher than INM and inorganic treatment. Similarly the highest value $(174.49 \mu \mathrm{g} / \mathrm{g}$ dry soil) of MBC was recorded at $60 \mathrm{DAT}$ and it declined at crop harvest stage $(90.73 \mu \mathrm{g} / \mathrm{g}$ dry soil). Values of Fluorescein diacetate activity (FDA) were the highest (11.80 $\mu \mathrm{g}$ fluorescein $/ \mathrm{g}$ soil $/ \mathrm{hr})$ at $60 \mathrm{DAT}$ and declined further at crop harvest stage $(8.84 \mu \mathrm{g}$ fluorescein $/ \mathrm{g}$ soil $/ \mathrm{hr})$. The lowest values of all the three parameters were observed in case of inorganic nutrient management practices. The results clearly indicated that organic nutrient management was responsible for higher microbial activities in the soil.

\section{Introduction}

Rice is India's prominent crop, and is also the hub of food security of the global population (Kumar et al., 2014). Rice supplies 20 and $31 \%$ of total calories required by world and the Indian population, respectively. After the green revolution the continuous use of dwarf varieties responsive to the fertilizers in intensive agriculture enhanced the agriculture production but at the same time it deteriorated the soil quality and total factor productivity (Vaid et al., 2014). Rice crop plants are able to use about $30-50 \%$ of the applied fertilizer $\mathrm{N}$ while more than $50 \%$ is lost from the soilplant system through leaching, volatilization and denitrification (Tiwari et al., 1998). With a view to reduce the losses and indiscriminate use of chemical fertilizers, substitution of a part of the chemical fertilizer by microbial inoculants is inevitable. Under the present situations organic and microbial nutrient sources could be important components of the nutrient management in different agro 
ecosystems since they are cost-efficient (Das et al., 2014). In addition to supply of nutrients, these organic and microbial inoculants improve the physical condition and biological health of soil, which improves the availability of applied and native nutrients (Shahane et al., 2013; Meena et al., 2014).

Generally higher enzymatic activity is associated with high quantity of organic matter in soil, which is directly related higher microbial activity in soil. Rose et al., (2014) in Vietnam also observed that the biofertilizer can replace between 23 and $52 \%$ of nitrogen (N) fertilizer without loss of yield. Keeping this in view, the present study was undertaken to study the effect of nutrient management practices and microbial inoculants on microbial properties in soil of lowland rice.

\section{Materials and Methods}

\section{Study area}

The field experiment was conducted during Kharif 2016 at the research farm of ICAR Complex for NEH Region (Umiam) Barapani, Meghalaya, situated at $950 \mathrm{~m}$ above mean sea level at latitude of $2541^{\prime}-21 " \mathrm{~N}$ and longitude of $9155 '-25 \mathrm{E}$. The soil of the experiment site was sandy clay loam in texture, acidic (5.0) in nature and having low available $\mathrm{N}$ (252.98 $\mathrm{kg} / \mathrm{ha})$ and $\mathrm{P}(8.19 \mathrm{~kg} / \mathrm{ha})$, but high in available $\mathrm{K}$ content and soil organic carbon $(2.51 \%)$ content.

\section{Treatments and experimental design}

The experimental treatments were consisted of 3 main plot treatment viz. 100\% organic, $100 \%$ inorganic (RDF) and integrated nutrient management INM (75\% RDF+ 25\% FYM) while in the sub plot there were 4 treatments viz. control, Azospirillum, Azospirillum + Phosphate solubilizing bacteria (PSB), Azospirillum + PSB + Zinc solubilizing bacteria $(\mathrm{ZnSB})$. For organic, FYM was taken as a source of nutrition. The experiment was laid out in split plot design with 3 replications. $\mathrm{N}, \mathrm{P}$ and $\mathrm{K}$ were applied through urea, single super phosphate and muriate of potash in the ratio of $80: 60: 40 \mathrm{~kg} / \mathrm{ha}$, respectively for inorganic nutrient management. While nutrient in organic plot was applied through FYM and through rock phosphate. In INM plots it was applied through $75 \%$ RDF and 25\% FYM. Biofertilizers were applied as per the recommended concentration and after dissolving in water roots of the seedlings were dipped in the solution. Popular rice variety 'Shahsarang 1' was taken in the experiment.

\section{Soil samples collection and analysis}

Soil samples were collected at 60 days after transplanting (DAT) and at harvest stage from all the plots of the experiment from $0-15 \mathrm{~cm}$ of soil layer. Then samples were analyzed as per the standard procedures in the lab for the estimation of microbial activity.

\section{Microbial biomass carbon (MBC)}

Microbial biomass carbon in soil samples was estimated by the method described by Vance et al., (1987).

\section{Alkaline phosphatase activity}

The activity of alkaline phosphatase in soil was assayed by a method developed by Tabatabai and Bremner (1969).

\section{Fluorescein diacetate (FDA) activity}

The activity of alkaline phosphatase in soil was assayed by a method developed by Tabatabai (1994).

\section{Results and Discussion}

Nutrient management practices and microbial inoculants showed significant influence on the 
soil microbial biomass carbon (MBC) at 60 DAT and at crop harvest stage (Table 1). The organic nutrient treatment was having significantly higher $\mathrm{MBC}$ as compared to INM and inorganic treatment at 60 DAT and at crop harvest. The maximum $(174.49 \mu \mathrm{g} / \mathrm{g}$ dry soil) value of $\mathrm{MBC}$ was recorded with organic nutrient management at 60 DAT and it declined at crop harvest stage $(90.73 \mu \mathrm{g} / \mathrm{g}$ dry soil).

This might be due to higher microbial activities in those plots where organic sources of nutrients were applied and lower value were observed in inorganic plots because inorganic sources of nutrients have some inhibitory effect on the microbial activity. Rao (1978) also found the similar result and reported that biological nitrogen fixation in the soil was low when the concentration of added nitrogen fertilizer was increased. Among the treatment with microbial inoculants, highest value of $\mathrm{MBC}$ was observed with combined inoculation of Azospirillum + PSB $+\mathrm{ZnSB}$ treatment at 60 DAT $(164.74 \mu \mathrm{g} / \mathrm{g}$ dry soil) and at harvest (85.69 $\mu \mathrm{g} / \mathrm{g}$ dry soil). Control treatment showed significantly lowest MBC compared to treatment having microbial inoculants at both the observations. There was gradual increase in MBC due to the inoculation of sole Azospirillum and combined inoculation of Azospirillum+ PSB and Azospirillum+ $\mathrm{PSB}+\mathrm{ZnSB}$. Alagappan and Venkitaswamy (2016) also reported higher microbial population, when nutrients were applied through organic treatments compared to application through RDF through mineral fertilizers and INM. Meena et al., (2014) also reported significantly enhanced $\mathrm{MBC}$ with application of $2 / 3 \mathrm{~N}+$ bacterial inoculants + cyanobacterial inoculants + Compost @ 5.0 $\mathrm{t} /$ ha over $\mathrm{N}$ control and chemical fertilizer application at recommended dose.

Table.1 Microbial properties of soil as affected by nutrient management practices and microbial inoculants in lowland rice

\begin{tabular}{|c|c|c|c|c|c|c|}
\hline \multirow[t]{2}{*}{ Treatment } & \multicolumn{2}{|c|}{$\begin{array}{l}\text { Alkaline phosphatase } \\
\text { activity at harvest ( } \mu \mathrm{g} \\
\text { p-NP/g soil/ hr) }\end{array}$} & \multicolumn{2}{|c|}{$\begin{array}{l}\text { FDA enzyme } \\
\text { activity }(\mu \mathrm{g} \\
\text { fluorescein/g } \\
\text { soil/hr) }\end{array}$} & \multicolumn{2}{|c|}{$\begin{array}{c}\text { MBC }(\mu \mathrm{g} / \mathrm{g} \text { dry } \\
\text { soil })\end{array}$} \\
\hline & $60 \mathrm{DAT}$ & Harvest & $60 \mathrm{DAT}$ & Harvest & $60 \mathrm{DAT}$ & Harvest \\
\hline \multicolumn{7}{|c|}{ Nutrient management practices } \\
\hline Organic* & 162.58 & 111.83 & 11.80 & 8.84 & 174.49 & 90.73 \\
\hline Inorganic $* *$ & 113.93 & 73.93 & 10.01 & 7.41 & 136.40 & 70.96 \\
\hline $\mathrm{INM} * * *$ & 131.23 & 84.73 & 11.54 & 8.64 & 151.01 & 78.60 \\
\hline $\mathrm{S}$ Em \pm & 4.07 & 2.98 & 0.16 & 0.14 & 3.29 & 1.63 \\
\hline $\mathrm{CD}(\mathrm{P}=0.05)$ & 16.08 & 11.92 & 0.63 & 0.56 & 12.94 & 6.48 \\
\hline \multicolumn{7}{|l|}{ Microbial inoculants } \\
\hline Control & 113.95 & 67.83 & 10.32 & 7.55 & 138.54 & 72.08 \\
\hline Azospirillum & 117.97 & 75.75 & 11.15 & 8.32 & 153.64 & 79.96 \\
\hline Azospirillum + PSB & 149.15 & 104.15 & 11.40 & 8.56 & 158.95 & 82.65 \\
\hline Azospirillum $+\mathrm{PSB}+\mathrm{ZnSB}$ & 160.59 & 115.59 & 11.59 & 8.74 & 164.74 & 85.69 \\
\hline $\mathrm{S} E \mathrm{Em} \pm$ & 4.44 & 4.25 & 0.11 & 0.11 & 2.44 & 1.24 \\
\hline $\mathrm{CD}(\mathrm{P}=0.05)$ & 13.18 & 12.77 & 0.33 & 0.34 & 7.27 & 3.75 \\
\hline Interaction & NS & NS & NS & NS & NS & NS \\
\hline
\end{tabular}


Like MBC, the similar trends were also observed in case of Fluorescein diacetate activity (FDA) as well as alkaline phosphatase activity. The highest value of soil FDA was recorded under organic nutrient management at 60 DAT $(11.80 \mu \mathrm{g}$ fluorescein/g soil/hr) and at crop harvest (8.84 $\mu \mathrm{g}$ fluorescein/g soil/hr) and those were significantly higher than INM and inorganic treatment. The highest value of alkaline phosphatase activity was recorded under organic nutrient management at 60 DAT (162.58 $\mu \mathrm{g} \mathrm{p-NP/g} \mathrm{soil/} \mathrm{hr)} \mathrm{and} \mathrm{after}$ harvesting (105.92 $\mu \mathrm{g} \mathrm{p}-\mathrm{NP} / \mathrm{g}$ soil/ $\mathrm{hr})$ and at both the observations it was significantly higher than INM and inorganic treatment. A gradual enhancement in soil alkaline phosphatase activities was found due to the inoculation of sole Azospirillum and combined inoculation of Azospirillum + PSB and Azospirillum+ PSB+ ZnSB. Yadav (2015) also reported increase in enzymatic activities in soil at harvest stage of rice crop due to the integrated application of microbial inoculants (PSB and AMF) over $\mathrm{P}$ control. The lowest values were recorded with inorganic practice at both the stages.

It was concluded that among the different nutrient management practices, organic sources of nutrient was responsible for the higher microbial activity in soil. Among the different microbial inoculants, combined application of Azospirillum $+\mathrm{PSB}+\mathrm{ZnSB}$ resulted into higher microbial activity over the other treatments.

\section{References}

Alagappan, S., and Venkitaswamy, R. 2016. Impact of different sources of organic manures in comparison with TRRI practice, RDF and INM on growth, yield and soil enzymatic activities of rice-greengram cropping system under site-specific organic farming situation.
American-Eurasian Journal of Sustainable Agriculture 10(2): 1-9.

Das, A., Patel, D. P., Munda, G. C., Ramkrushna, G. I., Kumar, M. and Ngachan, S. V. 2014. Improving productivity, water and energy use efficiency in lowland rice (Oryza sativa) through appropriate establishment methods and nutrient management practices in the mid-altitude of northeast India. Experimental Agriculture 50(3): 353-375.

Kumar, A., Meena, R. N., Yadav, L. and Gilotia, Y. K. 2014. Effect of organic and inorganic sources of nutrient on yield, yield attributes and nutrient uptake of rice cultivar PRH-10. The Bioscan 9(2): 595-597.

Meena, R. K., Singh, Y. V., Lata, A., Kumar, A., and Bana, R. S. 2014. Effect of plant-growth-promoting rhizobacteria inoculation on plant growth, productivity and economics of Basmati rice. Egyptian Journal of Biology 16(1): 45-50.

Rao, A. U., Murthy, K. M. D., Raju, T. S. S. K. and Lakshmi, D. A. Received: 8th Aug-2014 Revised: 5th Sept-2014 Accepted: 6th Sept-2014 Research article: studies on performance of organic farming and chemical farming in rainy season rice.

Rose, M. T., Phuong, T. L., Nhan, D. K., Cong, P. T., Hien, N. T. and Kennedy, I. R. 2014. Up to $52 \% \mathrm{~N}$ fertilizer replaced by biofertilizer in lowland rice via farmer participatory research. Agronomy for Sustainable Development 34(4): 857-868.

Shahane, A. A., Singh, Y. V., Kumar, D., Prasanna, R. and Chakraborty, D. 2015. Effect of planting methods and cyanobacterial inoculants on yield, water productivity and economics of rice cultivation. Journal of Agriculture and Rural Development in the Tropics 
and Subtropics (JARTS) 116(2): 107121.

Tabatabai, M.A., 1994. Soil enzymes. In: Weaver, R.W., Angle, J.S., Bottomley, P.S. (Eds.), Methods of Soil Analysis, Part 2 Microbiological and Biochemical Properties. Soil Science Society of America, Madison, WI, p. 755.

Tabatabai, M.A., and Bremner, J.M. 1969. Use of p-nitrophenyl phosphate assay of soil phosphatase activity. Soil Biology and Biochemistry 1: 301-307.

Tiwari, V.N., Lehri, L.K. and Pathak, A.N. 1989. Effect of inoculating crops with phospho-microbes. Experimental Agriculture 25: 47-50.

Vaid, S. K., Kumar, B., Sharma, A., Shukla,
A. K. and Srivastava, P. C. 2014. Effect of $\mathrm{Zn}$ solubilizing bacteria on growth promotion and $\mathrm{Zn}$ nutrition of rice. Journal of soil science and plant nutrition 14(4): 889-910.

Vance, C.P., 2001. Symbiotic nitrogen fixation and phosphorus acquisition. Plant nutrition in a world of declining renewable resources. Plant Physiology 127: 390-397.

Yadav, D., Singh, Y. V., Kumar, D., Gaind, S. and Kumar, A. 2015. Influence of sources and rates of phosphorus on plant growth, productivity and economics of aerobic rice (Oryza Sativa). Indian Journal of Agronomy 60(1): 157-159.

\section{How to cite this article:}

Parkash Verma, Y.V. Singh, Anil K. Choudhary and Sunita Gaind. 2017. Microbial Properties of Lowland Rice Soil as Affected by Nutrient Management Practices and Microbial Inoculants. Int.J.Curr.Microbiol.App.Sci. 6(10): 3415-3419. doi: https://doi.org/10.20546/ijcmas.2017.610.401 